\title{
SOCIAL DETERMINANTS OF COMMUNITY HEALTH \\ WITH THE EVENT OF DIABETES MELLITUS \\ (Study of Health Sociology in Makassar City)
}

\author{
Shermina Oruh; Andi Agustang; Andi Dody May Putra Agustang \\ Universitas Negeri Makassar, Indonesia \\ shoruh68@gmail.com, andi.agustang@unm.ac.id, andidodi044@gmail.com
}

\begin{abstract}
There are 148,311 people with Diabetes Mellitus in South Sulawesi, and 34,564 (23.30\%) of them are patients who receive standard services, domiciled in Makassar City. This study aims to determine the social determinants of urban public health with the incidence of diabetes mellitus.

The research method is qualitative, the type of research is a case study of five families in Makassar City. The results of the study indicate that aspects of knowledge, social environment, and institutions are the determinants of DM cases in urban communities. This aspect is determined by unhealthy social behavior based on genetic factors, age, and lifestyle. The better the knowledge, environment, and institutions that are owned, will form healthy social behavior in dealing with DM sufferers.
\end{abstract}

Keywords: diabetes mellitus, knowledge, social environment, institutions, genetics, age, lifestyle

\section{INTRODUCTION}

Diabetes Mellitus (DM) is a chronic disease characterized by high blood sugar levels. Insulin, which is a hormone that regulates the balance of blood sugar levels, is not produced enough by the pancreas. There are two categories of Diabetes Mellitus, namely, type 1 diabetes caused by heredity and type 2 diabetes caused by lifestyle (Andi Agustang, 2014). The modern lifestyle is a risky community culture if it is not followed by healthy social behavior. Lifestyle factors can put individuals, families, and communities at risk levels (Salmah Ummu et al., 2013) .

Data from the International Diabetes Federation (IDF), states that Indonesia is on diabetes alert status because it ranks 7th out of 10 countries with the highest number of diabetic patients. The prevalence of patients with diabetes in Indonesia reaches 6.2 percent, which means that more than 10.8 million people are suffering from diabetes by the year 2020. IDF also stated that now there are around 230 million people with Diabetes Mellitus, this figure continues to increase to 3 percent or around 7 million people annually, thus the number of people with Diabetes Mellitus (DM) is expected to reach 350 million by 2025 and half of that number is in Asia, especially India, China, Pakistan, and Indonesia .

The 2018 Basic Health Research (RISKESDAS) recorded the prevalence of diabetes in Indonesia reached 10.9 percent and is predicted to continue to increase. RISKESDAS also stated that as many as two-thirds $(2 / 3)$ of the Indonesian population did not know that they had diabetes. This is a threat because it leads to the low quality of Indonesia's human resources. Diabetes is also known to be one of the most common comorbidities found in Covid-19 patients, in addition to hypertension and 
cardiovascular disease (Andi Agustang \& Oruh, 2021). Based on data from the Ministry of Health (Kemenkes) on May 1, 2020, out of 800 cases of death due to Covid-19, 83 cases of diabetes were found. Diabetic patients with Covid-19 tend to be heavier and more likely to die if they are hospitalized. The Health Profile of South Sulawesi Province in 2019 noted that there were 148,311 DM sufferers, and 34,564 (23.30\%) of them were patients who received standard services who were domiciled in Makassar City (South Sulawesi Health Profile, 2020).

Based on this situation, a specific and in-depth study of the social determinants of public health is needed in the form of social behavior in families with DM in terms of knowledge, environment, and institutional aspects, as well as paying attention to genetic, age and lifestyle factors.

\section{METHOD}

This research is qualitative research, with the type of case study research that aims to describe the social determinants of urban public health in five families with diabetes mellitus in Makassar City. The subjects of this study were families who had diabetes who were used as informants with the following criteria: had a medical history of suffering from DM, the family had a genetic history of diabetes mellitus, had suffered from diabetes mellitus for at least 5 years both type I and type II, was undergoing treatment regularly. medical or traditional, are willing to provide information about the disease they are suffering from. The focus of the research is the social behavior and the determinants of DM. The research sub-focus for social behavior is seen from the aspects of knowledge, environment, and institutions. While the determinants of DM are genetic factors, age, and lifestyle. Data collection with snowball technique, observation, and in-depth interviews (5). Reduction, presentation, and verification are used as data analysis techniques (Andi Agustang, 2021a) .

\section{RESULT AND ANALYSIS}

MAL informant, male, 51 years old, works as a civil servant.

\section{$\underline{\text { Knowledge Aspect }}$}

The results of the analysis from the interview revealed that MAL did not know the early symptoms of the DM he was suffering from. MAL has an educational background in S1 Sozopol. MAL understands DM as a hereditary or genetic disease, so MAL ignores the disease because they feel that they do not have a family history of DM. MAL lacks information in handling DM, so it pays less attention to the type of food consumed. This shows the low level of informal knowledge possessed, MAL consumes food according to taste without paying attention to the nutritional value and balance contained in the food. 


\section{$\underline{\text { Social Environment Aspect }}$}

The results of the analysis from the interview revealed that MAL received advice from his wife, children, and neighbors to consume foods that contain low sugar. This means that informants are willing to accept input and always interact with the social environment internally and externally. Internally, the wife and children play an important role in finding information on traditional medicine for type I DM, and it is shown by MAL with adherence to a healthy lifestyle. Externally, it is shown by neighbors and office colleagues who always provide advice for the management of DM, and informants try to receive input by paying attention to eating habits, resting, and exercising regularly.

\section{$\underline{\text { Social Environment Aspect }}$}

The results of the analysis from the interview revealed that MAL received advice from his wife, children, and neighbors to consume foods that contain low sugar. This means that informants are willing to accept input and always interact with the social environment internally and externally. Internally, the wife and children play an important role in finding information on traditional medicine for type I DM, and it is shown by MAL with adherence to a healthy lifestyle. Externally, it is shown by neighbors and office colleagues who always provide advice for the management of DM, and informants try to receive input by paying attention to eating habits, resting, and exercising regularly.

Based on these three aspects, it is concluded that MAL in developing the concept of social behavior from the aspect of knowledge is not supported by educational background to understand the DM he suffers from. The social environment aspect is carried out by always interacting with the internal and external environment both from family, neighbors, and the surrounding community for the handling of DM. The institutional aspect is carried out with medical treatment and alternatives for healing.

Factors that determine a person can suffer from DM include genetic factors, age, and lifestyle:

\section{$\underline{\text { Genetic Factors }}$}

The results of the interview show that genetic factors affect a person suffering from DM. Early action is needed so that it does not happen to other family members by maintaining health and living a healthy lifestyle. MAL was diagnosed as having DM from the father's gene. Efforts made are medical treatment, by taking medication when you feel symptoms of the disease. The informant's action on the illness he suffered was by advising the family to pay attention to health, especially paying attention to weight, food consumed, and often exercising.

\section{$\underline{\text { Age Factor }}$}

The results of the interview showed that from the diagnosis, it was found that MAL had DM when he was 45 years old, where his stamina began to decline. Efforts are made to check with a doctor and 
avoid consuming foods that contain sugar. The action taken by MAL informants is to maintain health conditions through improving a healthy lifestyle, paying attention to a regular diet, getting enough rest, and doing activities according to the level of physical ability.

\section{Lifestyle Factor}

The results of the interview show that the MAL lifestyle does not consider health, such as frequent eating out. Efforts are being made to prevent DM disease by reducing gatherings with friends and accepting advice on choosing foods that do not contain sugar. Actions taken by informants to maintain health conditions are to invite them to gather at home or take the time to rest.

DM disease suffered by MAL informants is a genetic factor obtained from his father's genes. Efforts and actions taken are through medical treatment and paying attention to health conditions. MAL suffered from DM when she was 45 years old, so the informant tried to avoid consuming foods containing sugar and to make improvements to a healthy lifestyle. MAL also suffers from DM due to lifestyle, which does not consider health, such as eating out with friends and lack of rest.

NAM informant, male, 63 years old, has suffered from DM for the last 5 years.

\section{Knowledge Aspect}

The results of the analysis from the interview can be said that NAM understands DM as a hereditary disease from parents. NAM informants have basic knowledge about food substances that must be avoided and can be consumed by people with DM. Judging from formal knowledge, informants understand that there are two types of DM disease. This means that the informant understands the DM he suffers and can survive with DM. As for the informal knowledge aspect, NAM informants always follow the doctor's advice to take medication regularly and lead a healthy lifestyle.

\section{$\underline{\text { Social Environment Aspect }}$}

The results of the analysis of the interview can be said that the NAM informants received attention from their children, in-laws, and neighbors for the treatment of their illness. Aspects of the social environment internally, the informant received input from relatives for the treatment of DM, which means the informant showed obedience according to input from relatives for the treatment of DM. External aspects, informants interact with neighbors to find out whether health developments are progressing or not. This means that the informant received many recommendations from neighbors for the treatment of DM.

\section{$\underline{\text { Institutional Aspect }}$}

The results of the analysis of the interview can be said that the NAM informants show DM as a chronic disease that requires institutionalized treatment. This means that DM treatment can be 
handled by the government and non-government parties. Aspects of government social institutions, in this case, hospitals/Puskesmas, can take treatment measures, and recommend implementing the concept of healthy living. Furthermore, non-institutional, informants handle DM through alternative herbal medicines, for long-term treatment that has no side effects for the body.

NAM has known that DM is a hereditary disease and is trying to adopt a healthy lifestyle. Aspects of the social environment are always improved for social interaction and obedience in handling DM. The institutional aspect in dealing with the DM he suffers tends to be done by doing alternative medicine.

Factors that determine a person can suffer from DM include: genetic factors, age, and lifestyle:

\section{Genetic Factors}

The results of the interview mean that the informant always advises maintaining health because genetic factors affect someone suffering from DM. NAM suffers from DM due to genetic factors from his mother's genes. Efforts are made through medical and traditional treatment. This means that the informant made efforts to treat DM by making traditional ingredients and taking medicines recommended by doctors. Action in handling genetic factors is to provide input to families to maintain health and live healthily. This means that the informant advised their children to pay attention to the food they eat and not be too tired at work.

\section{$\underline{\text { Age Factor }}$}

The results of the interview showed that NAM suffered from DM when he was 59 years old, but from the doctor's information, the informant stated that the informant had long suffered from DM. Efforts are being made to carry out traditional and medical treatment as well as a healthy lifestyle. The action taken by the informant was to pray a lot and istighfar, take medicine regularly, and maintain nutritional intake.

\section{Lifestyle Factor}

The results of the interview show that after retiring NAM has no more activities, so his only desire is to eat without controlling what he eats. Efforts are being made to change eating patterns back to traditional ones, such as drinking boiled leaves, as well as attention from children and in-laws in preparing food and medicines to drink.

DM suffered by NAM informants is a hereditary disease from the mother. Efforts and actions taken are to do medical treatment and pay attention to food nutritional intake. NAM suffered from DM when he was 59 years old, carried out traditional and medical treatment as well as a healthy lifestyle. NAM also suffers from DM due to a sedentary lifestyle. 
Informant ZAK, male, 42 years old, works as a civil servant in an agency in Makassar City, has suffered from type II DM for the last 3 years.

\section{Knowledge Aspect}

The results of the analysis from the interview can be said that the ZAK informant knew that he had suffered from type II DM because he had wounds on his legs that did not heal plus he was overweight. From the aspect of formal knowledge, ZAK informants stated that they often consume unhealthy food and rarely exercise, and from the aspect of informal knowledge, it is seen that ZAK informants take medicine regularly, maintain nutritional intake of food and provide time for exercise.

\section{$\underline{\text { Social Environment Aspect }}$}

The results of the analysis of the interview can be said that ZAK informants get better attention from the family internally and externally. This means that the informant is willing to accept every input and is obedient enough to carry it out to cure the DM he suffers. Internally, attention from family and relatives so that the informant remains enthusiastic about living with DM for his recovery from type II DM. Externally, the informant also always interacted with neighbors and the community on weekends to add insight into the recovery from the DM he suffered.

\section{Institutional Aspect}

The results of the analysis from the interview can be said that ZAK routinely checks his health at the hospital and follows the hospital doctor's recommendations to take regular medication. The hospital for ZAK informants is believed to be able to handle DM patients from check-ups to treatment. Informants also use herbal drug therapy which is safe for long-term consumption and can increase stamina.

ZAK does not understand the symptoms of type II DM that he is experiencing. This is because, from the aspect of the social environment, there is less interaction internally and externally in dealing with the DM he suffers. ZAK combines medical and herbal treatment in dealing with his illness.

Factors that determine a person can suffer from DM include genetic factors, age, and lifestyle.

\section{$\underline{\text { Genetic Factors }}$}

The results of the interview showed that the informant was aware of the risks of the disease he suffered, so he always maintained his diet and advised his siblings to pay attention to the food they consumed and take regular breaks. ZAK stated that the DM he suffered was not caused by genetic factors but a lack of attention in consuming food. This means that the type II DM he suffered was due to not paying attention to food nutrition intake. Efforts made are medical treatment and living a 
healthy lifestyle. This means that the informant must take medication, have a healthy lifestyle, and exercise regularly. The actions taken were getting used to living with DM, following the doctor's advice, and advising the brothers and sisters to maintain a regular diet and rest.

\section{$\underline{\text { Age Factor }}$}

The results of the interview showed that ZAK suffered from type II DM from the age of 39-40 years. Healing efforts by doing a check-up once a month, exercising regularly, and taking medication. The actions taken are by always maintaining health, living a healthy lifestyle, staying away from sweet foods, exercising regularly, getting enough rest, taking the medication regularly.

\section{Lifestyle Factor}

The results of the interview show that ZAK's lifestyle is seen during breaks, where ZAK takes advantage of the time to have lunch together, either in the canteen, at a place to eat outside the office, or if there are regular meetings to eat at a cafe or restaurant. Efforts that are expected to be carried out are consulting with a doctor regarding the development of DM, once a month controlling blood sugar, taking the recommended medication, drinking milk and vitamins to stay fit at work.

ZAK suffers from DM not because of genetic factors but because of an unhealthy lifestyle. ZAK suffers from type II DM since the age of 39-40 years. Healing efforts and actions include checking up once a month, exercising regularly, and taking medication. Reducing the habit during recess by having lunch together in the cafeteria, cafe, or restaurant is an unhealthy lifestyle.

The PAE informant, male, 52 years old, works as a private employee at a company in Makassar City, has suffered from type II DM for four years.

\section{Knowledge Aspect}

The results of the analysis from the interview can be said that the PAE informant understands the DM he suffers, but does not maintain his nutritional intake, causing him to suffer from DM. In dealing with his illness, the informant took medication according to the doctor's recommendations and exercised regularly.

\section{Social Environment Aspect}

The results of the analysis from the interview can be said that PAE received recommendations from family and neighbors because the informants were still not obedient and obedient to carry out the recommendations given. Informants are less willing to accept input. This means that the informants showed less socialization with family and relatives because they did not want to cause trouble. Furthermore, the external social environment is seen as an interaction shown by receiving attention 
from neighbors and friends. This means that the informant still does not want to bother other people but still receives the attention given to him.

\section{$\underline{\text { Institutional Aspect }}$}

The results of the analysis from the interview can be said that PAE visited the hospital for a health check and consulted a doctor. For PAE informants, the hospital is the choice to check for DM. In terms of non-government institutions, it appears that PAE informants do not use herbal products and alternative medical therapies for the treatment of DM, which means that PA informants are less interested in using alternative treatments because of the long healing process.

PAE has less knowledge about nutrition that must be consumed by DM patients. PAE also lacks socialization internally with his family to deal with the DM he is experiencing, including not paying attention to suggestions from his neighbors. However, PAE has more respect for hospital services as a means of treatment.

Factors that determine a person can suffer from DM include genetic factors, age, and lifestyle.

\section{Genetic Factors}

The results of the interview show that genetic factors influence a person suffering from DM. PAE informants anticipate this by paying attention to children for healthy living. From the doctor's diagnosis, PAE had type II DM due to genetic factors from his father. Efforts are made by regularly taking medicine from a doctor, trying herbal and traditional remedies. The action taken is to relax with DM and advise the family to pay attention to health.

\section{Age Factor}

The results of the interview showed that PAE was diagnosed with DM when he was 49 years old. Efforts are made by using herbal and traditional treatment methods. The actions taken by the informants were to accept the reality of living with DM, avoid eating too sweet foods and advise children to live a healthy life.

\section{Lifestyle Factor}

The results of the interview show that the PAE lifestyle can be seen from the frequent consumption of fast food which is sold to fill the stomach at lunchtime. Efforts are being made to treat DM by using herbal treatment methods. Actions are taken by informants to maintain health conditions by praying a lot and being patient as well as resting and exercising. 
The DM disease suffered by the PAE informant is a derivative of the father's gene. PAE developed DM at the age of 49 years. PAE performs herbal and traditional treatments and leads a healthy lifestyle. Having a lifestyle, the habit of eating fast food as a practical menu at lunchtime.

PON informant, male, 68 years old, suffering from type II DM for 4 years.

\section{Knowledge Aspect}

The results of the analysis from the interview can be said that the PON informants know enough about the DM he suffers, which is a hereditary disease. The informant admitted that DM was caused by consuming too much rice and sweet foods. The informant took the medicine given by the doctor and consumed a lot of water. This means that in addition to following the doctor's advice to take medicine regularly, the informant also does drinking water therapy to cure his illness.

\section{$\underline{\text { Social Environment Aspect }}$}

The results of the analysis of the interview can be said that the PON informants received attention from family, relatives, and neighbors. Informants are willing to receive input from their social environment, both internal and external. The social environment internally comes from the family and relatives who always pay attention to the healthy development of the informants. The social environment externally comes from neighbors who pay attention to the recovery of the informants, which means that the informants are happy to socialize and all residents around the complex.

\section{Institutional Aspect}

The results of the analysis from the interview can be said that PON gets attention from the family to go to the hospital and undergo alternative treatment but tends to prefer alternative/traditional medicine in the treatment of DM. PON informants are not interested in conducting further examinations to the hospital. Informants are more interested in non-governmental institutions, more interested in alternative and traditional medicine to treat DM.

From the aspect of knowledge, PON does not understand the things that need to be done to prevent and treat the disease. This is due to a lack of socializing with the internal and external environment for healing DM. This condition is reinforced by the choice of non-government institutions as a means of treatment, namely using traditional medicine when the DM is acute.

Factors that determine a person can suffer from DM include: genetic factors, age, and lifestyle:

\section{$\underline{\text { Genetic Factors }}$}

The results of the interview show that the informants always advise maintaining health because genetic factors affect someone suffering from DM. PON realized that the DM he suffered was due to 
genetic factors or inherited from his mother's genes. Efforts are made through medical and traditional treatment. Action in handling genetic factors is to provide input to families to maintain health and live healthily.

\section{$\underline{\text { Age Factor }}$}

The results of the interview showed that PON had suffered from DM for a long time but only had an examination with the doctor when he was 64 years old. Efforts have been made to treat DM traditionally by regulating a balanced diet. Actions are taken by regularly checking health to the doctor and adjusting the diet by avoiding sweet foods, replacing rice with corn or potatoes, and drinking lots of water.

\section{Lifestyle Factor}

The results of the interview showed that the cause of DM informants was PON due to lack of activity, irregular eating patterns. Efforts are made to maintain nutritional intake through a balanced diet. The action taken is the attention of the family to lead a healthy lifestyle.

DM disease suffered by PON informants is a derivative of the mother's gene. The treatment is done medically and traditionally as well as maintaining a healthy lifestyle. An unhealthy lifestyle due to lack of activity, irregular eating patterns support the occurrence of DM. Judging from the age factor, PON has suffered from DM for a long time. Efforts to take traditional healing actions by regulating a balanced diet.

\section{DISCUSSION}

The increasing flow of globalization in all fields has brought many changes to people's behavior and lifestyle, including a healthy lifestyle. These changes have unwittingly influenced the epidemiological transition with the increasing number of cases of non-communicable diseases such as diabetes. The social behavior of the urban community with DM is identical to the identity of a person's personality in socializing in society which is reflected in aspects of knowledge, environment, and social institutions. While the factors that determine the social behavior of urban communities with DM are reflected in genetic factors, age, and lifestyle.

\section{Social Behavior of Urban People with DM}

The tendency of urban people to behave that is not by a healthy lifestyle is caused by three aspects:

\section{a. Knowledge Aspect}

The cause of differences in a person's level of knowledge in disseminating social behavior to self, family, and society is due to different levels of knowledge according to formal and informal educational backgrounds. The understanding of social behavior is seen 
from the aspect of knowledge, this is supported by the theory of social behavior that the heart of sociology lies in the study of interaction and individual behavior. This interaction makes individual life dynamic and individual behavior is formed from social dynamics (7). This view of Homans has relevance to what was stated by Tunner in Ritzer (2010:87) about the theory of ideology and utopia.

The discussion of social behavior seen from the aspect of knowledge also has relevance to research conducted by Aditya Sumartono (8) (2012) and Mahmud Salahuddin (2012). Aditya's research findings recommendations provide answers to the problem that the causes of unhealthy lifestyle behaviors that occur in Jakarta are caused by low socialization, environment, and adoption of healthy lifestyles. Sociologically it provides a proposition that the low level of social interaction and behavior affects the treatment of the community in socializing and taking actions to live a healthy life. Likewise, the results of Mahmud Salahuddin's research reveal a phenomenon that the dynamics of people's lives are largely determined by the social behavior they implement. There are two sides in looking at the dynamics of social behavior in society, namely the dynamics of the healthy paradigm and the sick paradigm (Andriana et al., 2021).

Previous research has similarities about the importance of social behavior related to health in a society. The difference in this study lies in the point of view of the observed focus, the two previous studies focused on macro-sociological studies, while this study tends to look at the micro-sociology perspective. Thus it can be said that the knowledge of the urban community becomes an important aspect in social behavior in dealing with DM.

\section{b. Environmental Aspect}

The environmental aspect is the subject and object of sociology. The environment as a subject of sociology, namely the existence of the environment can determine the quality of the environment needed by humans as a living space and activity space (10). The environment as an object of sociology is the environment as a means to interact and behave by human needs (11). Directly and indirectly, aspects of the social environment in human life are distinguished into the internal environment and the external environment.

This understanding of social behavior from the environmental aspect is supported by social systems theory that the social system is a dynamic balance system that regulates the regularity of the elements of society (12). The linkage of social system theory is more comprehensive by understanding the theory put forward by Talcott Pearson in Ritzer (2010: 84) which introduces the theory of system structure that in society there are system structures in the form of behavioral systems, personality systems, social systems, and cultural systems. These four system structures form the "AGIL" scheme (adaptation, goal, integration, latent) (13). This is the same assumption as the healthy paradigm theory which refers to the equilibrium theory that the cause of a disorder or disease occurs because there is no balance 
between humans (host), disease (agent), and the environment (environment) which has an impact on dominant resistance. (Andi Agustang, 2021b). Wright (2009: 66) states that changes in social behavior determine the healthy paradigm experienced by a person in adapting to his environment .

The discussion on social behavior also has relevance to research conducted by Elis Ningsih Ningrum (2011), Sebastian Wahono (2011), and La Ode Katri (2012). The recommendations of this study highlight the importance of building a healthy social behavior paradigm by improving the balance of interactions between humans as hosts, DM as an agent, and the family environment as an environment. DM sufferers increase or decrease depending on the social system in the community, so it is necessary to structure an action system in dealing with DM patients to provide a social approach to a healthy environment (health social environment) through a healthy paradigm that is by regular eating patterns, rest patterns. adequate and balanced activity patterns. This pattern can be applied properly if the social behavior of the community supports efforts to reduce the level of DM sufferers in urban communities in particular and Indonesian society in general.

The discussion on social behavior also has relevance to research conducted by Elis Ningsih Ningrum (2011), Sebastian Wahono (2011), and La Ode Katri (2012). The recommendations of this study highlight the importance of building a healthy social behavior paradigm by improving the balance of interactions between humans as hosts, DM as an agent, and the family environment as an environment. DM sufferers increase or decrease depending on the social system in the community, so it is necessary to structure an action system in dealing with DM patients to provide a social approach to a healthy environment (health social environment) through a healthy paradigm that is by regular eating patterns, rest patterns. adequate and balanced activity patterns. This pattern can be applied properly if the social behavior of the community supports efforts to reduce the level of DM sufferers in urban communities in particular and Indonesian society in general.

\section{c. Institutional Aspect}

Social behavior in the community cannot be separated from the contribution of social institutional aspects, both government institutions, and non-government institutions. The understanding of social behavior seen from the institutional aspect is supported by the theory of significant symbols proposed by Mead in Ritzer (2010: 278) that in social interaction everyone has significant symbols to realize their social goals. Significant symbols that exist in society are institutions, both formal and non-formal institutions (A. Agustang \& Oruh, 2017). This theory has relevance to the theory of symbolic interactionism proposed by Blummer et al in Ritzer (2010: 289) which states that one of the principles of this theory is that humans can think to make social interactions. This means that the social behavior of a society with its symbolic interactionism is capable of giving birth to the theory of action and interaction proposed by Mead in Ritzer (2010:293). This theory is a contribution to the theory of outward behavior and hidden 
behavior. Outward behavior is actual behavior, while hidden behavior is behavior from conditions outside of their nature, including in this case a person's ability to behave to make choices. Moving on from the ability to make choices, Erving Goffman in Ritzer (2010: 292) provides an institutional theory that everyone is a social actor who has a role in social institutions. The role is adjusted according to social paradigm, social definition, and social behavior perilaku .

The discussion on social behavior also has relevance to research conducted by Nugrah Wardana (2010), Sulistyo Hadipradja (2011), (Oruh et al., 2017) and Khahar Djaelani (2010). Understanding the recommendations of previous research results about this research, there are similarities, namely the three previous studies observing the existence of social behavior in the prospective institutional health sector. While the difference between the three previous studies with this research is the substance of the observed focus of the observations. The three previous studies focused on the field of health services in general, while this study focused on institutions dealing with DM sufferers. Thus it can be said that the institutional aspect is a forum for urban communities to behave socially in dealing with DM.

\section{Factors that Determine Social Behavior of Urban People with DM}

Factors that determine the social behavior of urban communities with DM in Makassar City from observations show that:

\section{a. Genetic Factors}

Genetic factors are one of the factors that affect the potential for each person to suffer from DM. Genetic factors are one of the important indications in diagnosing someone who has the possibility and suffers from DM by knowing whether both parents or one of them has DM (A Agustang, 2021).

The results showed that the diagnosis of DM patients was marked by their parents having had DM. Usually, there is a genetic factor in a person if the medical history of one or both parents has inherited genetics that is owned by his child. The potential for this genetic factor if prevention, treatment, and recovery measures are not taken, at a certain period scale will be the potential for someone to suffer from DM even though it is realized that everyone in their body has the potential for sugar content.

The results also show that genetic factors are a potential factor in someone suffering from DM. Therefore, it is necessary to understand and raise awareness for everyone who has indications that their parents have suffered from DM. Sometimes people ignore and don't care about things related to genetic factors as a potential cause of someone suffering from DM. Through increasing social behavior by adopting a healthy lifestyle, will have an impact on reducing DM sufferers from an early age.

Understanding of genetic factors as a determinant of someone suffering from DM is supported by social facts theory from Durkheim in Ritzer (2010:21) which states that 
behavior and changes determine social facts. The interpretation of this social fact theory about the genetics of people with diabetes can be interpreted as that behavior and changes in a person's self are facts that can be inherited biologically due to genetic inheritance. This is by Darwin's theory of natural selection in Ritzer (2010: 50) which states that social life cannot be separated from survival through an evolutionary process that develops based on genetic or inherited formations. This means that genetic factors in prospective sociology are an evolutionary process from generation to generation, including in this case the occurrence of communities with diabetes mellitus (Andi Agustang \& Oruh, n.d.).

The discussion of genetic factors also has relevance to research conducted by Mukhlis Harahap (2010), Sugiharti Kusuma (2012), and Wawan Supriawan (2010). Understanding the recommendations of previous research results about this research, there are similarities, namely the three previous studies observed the existence of genetic factors in determining social behavior in handling DM in urban communities. The difference between the three previous studies and this research lies in the approach used. The three previous studies used a health medical approach. While this research uses a health sociology approach. Thus, it can be said that genetic factors are the dominant factors in determining a person suffering from type I and type II DM according to the social behavior that is undertaken.

\section{b. Age Factor}

The age factor is one of the factors that affect a person suffering from DM (Sahabuddin et al., 2020). Where when the age has begun to be unproductive or physically decline and lack sufficient stamina to carry out activities. This means that as each person gets older, his health condition decreases, which is one of the determinants of a person's ease of suffering from disease, or in other words someone will be susceptible to DM.

Actions that must be taken at certain ages are attempted to be selective in consuming food, especially foods that are not balanced in nutritional value, avoid foods that contain excessive sugar. Increasing age must also be able to manage productive and effective times in activities, avoid tiring activities, fatigue, weakness, and stress (SHERMINA ORUH \& ANDI AGUSTANG, 2015). Try with increasing age, strive for physical activity the body is always moving such as exercising to balance the burning of substances in the body so that the condition of the body remains strong, fit and fresh.

An understanding of the age factor as a determinant of someone suffering from DM is supported by the rational choice theory proposed by Friedman in Ritzer (2010: 357). This theory focuses on actors. Actors are seen as human beings who have a purpose and have a purpose. This means that the age factor greatly determines a person's choice to determine his rational action. This rational choice theory correlates with the value proposition theory according to Homans in Ritzer (2010: 364) which states that the higher the value of a person's action for himself, the more likely he is to take that action. That is, in a person's life is always 
confronted by the value of interest actions (fulfillment of needs, activities, and rest), the more likely he is to take productive actions (Akbar et al., 2021).

The discussion on the age factor also has relevance to the research conducted by Mukhlis Harahap (2010), Sugiharti Kusuma (2012), and Wawan Supriawan (2010). Understanding the recommendations of previous research results about this research, there are similarities, namely the three previous studies observed the existence of the age factor in determining social behavior in handling DM in urban communities. The difference between the three previous studies and this research lies in the approach used. The three previous studies used a health medical approach. While this research uses a health sociology approach. Thus it can be said that the age factor plays a role in determining a person suffering from type I and type II DM according to the social behavior that is applied.

\section{c. Lifestyle Factor}

The development of urban life is synonymous with changes in status and identity that lead to the confirmation or recognition of the lifestyle played by everyone (Oruh et al., 2017). Therefore, lifestyle factors directly or indirectly greatly affect a person's social behavior in handling DM. The lifestyle referred to in this case is a habit that is repeated as a demand to fulfill things that are interrelated with the existence of each person's life. The lifestyle of urban people is very consumptive and collective.

An understanding of lifestyle factors as a determinant of someone suffering from DM is supported by the theory of modernity and identity proposed by Giddens (2010:221). This theory is characterized by symptoms of modernity, namely the transformation of self-identity and globalization. That is, people who cannot carry out modern reflexivity in their personal lives, then that person does not have an identity in globalization. This is what drives a person to have a lifestyle in social behavior and action. This theory is understood by Giddens to have a risk called the theory of experiential alienation, meaning that the reality and routine of daily life are always marked by the emergence of symptoms of madness, crime, disease, death, and sexuality as lifestyle risks. Based on this, Giddens (2010:224) introduced the theory of risky society, stating that lifestyle is a risky culture. This is more dangerous than the symptoms of modernization that do not direct the lifestyle. Therefore, there needs to be risk creation and the ability to cope with risk (Mukti et al., 2021).

The discussion on lifestyle factors also has relevance to research conducted by (20) Mukhlis Harahap (2010), Sugiharti Kusuma (2012), and Wawan Supriawan (2010). Understanding the recommendations of previous research results about this research, there are similarities, namely the three previous studies observing the existence of lifestyle factors in determining social behavior in handling DM in urban communities. The difference between the three previous studies and this research lies in the approach used. The three previous studies used a health medical approach. While this research uses a health sociology approach. 
Thus it can be said that lifestyle factors directly or indirectly affect a person's social behavior in determining the desired healthy pattern.

Based on this discussion, it can be concluded that the social determinants of urban public health are determined based on knowledge, environment, and social institutions without ignoring genetic, age, and lifestyle factors that determine a person suffering from DM. Thus, it can be said that the better knowledge, environment, and institutions they have, will form healthy social behavior in dealing with DM sufferers according to genetic factors, age, and lifestyle.

\section{CONCLUSION}

1. Urban communities in Makassar City tend to have unhealthy social behavior in dealing with DM disease as shown in the following aspects:

a. Knowledge of urban communities is an important aspect of social behavior in dealing with DM.

b. The social environment of urban communities shapes interaction behavior in handling DM.

c. Institutions as a forum for urban communities to act in dealing with DM.

2. The increasing number of DM sufferers in urban communities in Makassar City is influenced by several factors, namely:

a. Dominant genetic factors determine a person suffering from DM.

b. The age factor plays a role in determining a person suffering from type I and type II DM according to the social behavior that is applied.

c. Lifestyle factors directly or indirectly affect a person's social behavior in determining the desired healthy pattern.

\section{SUGGESTION}

1. Social behavior is needed in handling DM patients in the form of:

a. Increasing public knowledge through health education

b. Environmental improvement through intensive social interaction

c. Institutional strengthening both government and non-government in an integrated manner.

2. Urban communities need to consider the determinants of increasing DM sufferers:

a. Genetics, need to be socialized to everyone to do early treatment.

b. Age is a concern to be more careful in maintaining a healthy lifestyle.

c. Lifestyle needs to be interpreted positively according to a healthy lifestyle.

3. Being a solution for interested parties to improve the social behavior of urban communities in dealing with DM sufferers, as well as being a contribution for those who want to continue this research in other aspects of sociological studies. 


\section{Bibliography}

Agustang, A., \& Oruh, S. (2017). Factors affecting of heropnam of mental disorders in Dadi Regional Hospital in South Sulawesi Province. Man in India, 97(11), 233-244.

Agustang, A. (2021). Teknologi Partisipasi Metode Fasilitasi Pembuatan Keputusan Partisipatif. In OSF Preprints.

https://scholar.google.com/citations?view_op=view_citation\&hl=en\&user=el8HzI0AAAA J\&pagesize $=100 \&$ citation_for_view=el8HzI0AAAAJ:6ZzL7HXColQC

Agustang, Andi. (2014). LIFE BEHAVIOR OF SOCIETY, FIVE CASES ON FAMILY OF

DIABETES MELLITUS PATIENTS IN MAKASSAR. International Journal of Academic Research, 6(1).

Agustang, Andi. (2021a). Filosofi Research Dalam Upaya Pengembangan Ilmu. OSF Preprints. Agustang, Andi. (2021b). \{IMPROVING $\}$ TTHE $\}\{$ QUALITY $\}$ \{OF $\}$ PPRIMARY\} \{HEALTH\} \{SERVICES\} $\{$ IN\} \{THE\} \{PERSPECTIVE\} \{OF\} \{PARTICIPATORY\} \{GOVERNANCE\}. https://doi.org/10.31219/osf.io/4kx6e

Agustang, Andi, \& Oruh, S. (n.d.). Etnomedik pada masyarakat bugis. 1-8.

Agustang, Andi, \& Oruh, S. (2021). KESEJAHTERAAN PSIKOLOGIS (studi Pada Dewasa Madya Yang Belum Menikah Di Kota Makassar).

Akbar, H., Oruh, S., \& Agustang, A. (2021). Indeks Prediktif Kejadian Demam Berdarah Dengue (DBD) di Kabupaten Indramayu. Jurnal Kesehatan, 14(2), 76-82. https://doi.org/10.32763/juke.v14i2.289

Andriana, Agustang, A., Idkhan, A. M., \& Hasriadi. (2021). Daya Tanggap Pelayanan Unit Gawat Darurat di Puskesmas Sarjo Kabupaten Pasangkayu . Journal Governance and Politics (JGP), 1(2 SE-Articles). https://e-journal.iyb.ac.id/index.php/jgp/article/view/201

Mukti, I., Oruh, S., \& Agustang, A. (2021). Efek Pemberitaan Kekerasan Di Media Sosial Terhadap Citra Negatif Kota Makassar. JISIP (Jurnal Ilmu Sosial Dan Pendidikan), 5(4).

Oruh, S., Agustang, A., \& Alim, A. (2017). Kejadian Heropnam Gangguan Jiwa Dan Faktor Yang Mempengaruhi Pada Rumah Sakit Khusus Daerah Dadi Provinsi Sulawesi Selatan. July.

Sahabuddin, E., Agustang, A., Manda, D., \& Oruh, S. (2020). Partisipasi Sosial Dalam Pemenuhan Activity Daily Living (Adl) Orang Dengan Gangguan Jiwa Di Kota Makassar. Phinisi Integration Review, 3(2).

Salmah Ummu, A., Idris, R., Agustang, A., \& Maidin, A. (2013). Socio-Cultural Transformation of Early Detection on Breast Cancer Suspect in Wahidin Sudirohusodo Hospital, Makassar Indonesia. International Journal of Engineering Research \& Technology (IJERT), 2(11), 1810-1818.

SHERMINA ORUH, \& ANDI AGUSTANG. (2015). PENGARUH PENGETAHUAN KELUARGA, STIGMA MASYARAKAT DAN KEPATUHAN MINUM OBAT TERHADAP KEKAMBUHAN PENYAKIT GANGGUAN JIWA DI KOTA MAKASSAR. In $D k$ (Vol. 53, Issue 9, pp. 1689-1699). https://doi.org/10.1017/CBO9781107415324.004 